\title{
MODELLING FACTORS CONNECTED WITH THE EFFECT OF INTERNATIONAL MIGRATION FOR SECURITY AND ECONOMY
}

\author{
Kateryna Berezka \\ Ternopil National Economic University, Ternopil, Ukraine \\ e-mail: km.berezka@gmail.com
}

ORCID: 0000-0002-9632-4004

\section{Olha Kovalchuk}

Ternopil National Economic University, Ternopil, Ukraine

e-mail: Olhakov@gmail.com

ORCID: 0000-0001-6490-9633

(C) 2019 Kateryna Berezka, Olha Kovalchuk

This is an open access article distributed under the Creative Commons Attribution-NonCommercial-NoDerivs license (http://creativecommons.org/licenses/by-nc-nd/3.0/)

DOI: 10.15611/eada.2019.4.03

JEL Classification: C15, E2, O15

\begin{abstract}
This article concerns research conducted on the casual connections between modern global migratory processes and basic socio-economic and safety indexes for countries around the world countries. On the basis of new official dataset there was developed a cluster model of countries distributed according to the basic indicators which characterize migratory streams (emigration/ immigration), safety and macroeconomic indexes, related to the international migration. It is established that, in general, people are moving to safer countries that can provide them with better opportunities and social guarantees. The factor models for emigration and immigration processes, and international migration in general have been constructed. The main factors that prompt people to change their place of residence and the economic and safe effects of unprecedented levels of international migration are revealed. The empirical research examined in this paper confirmed the causal link between the volumes of international migration flows and the growth of Foreign Direct Investment in home countries and the reduction of security in host countries. The lack of statistical connection between immigration and emigration flows has been established.
\end{abstract}

Keywords: international migrations, economic growth, safety, climate change, modeling.

\section{Introduction}

The modern world has become more open and interconnected than it was even a few decades ago. International migration has reached unprecedented levels and has touched almost all corners of the globe. In recent years, the flows of international 
migrants throughout the world have continued to grow rapidly. In 2017, their number reached 258 million [International Migration Report 2017... 2019].

At the same time, conflicts, poverty, inequality and the lack of sustainable livelihood more often make many people leave their homes in search of a better future for themselves and their families abroad. Only in 2018, nearly 70.8 million people were forcibly displaced around the world as a result of persecution, conflict, violence or human rights violations. Every minute, 25 people were forced to flee; 37,000 people left their homes every day. The global population of forcibly displaced increased by 2.3 million in 2018. In total, 70.8 million displaced persons live in the world today [Global Trends: Forced Displacement in 2018 ... 2019]. The civil war in Syria, conflicts in Africa and natural disasters around the world have forced millions to flee the land of their birth. The number of displaced persons globally has reached a record high level. Now one in every 113 people on the planet is a refugee. In general, every three seconds someone is forced to leave home [The number of... 2019]. The reasons are violence, armed conflicts, persecution, hunger, war for resources, cataclysms and abnormal natural phenomena.

Climate change, food shortages and clashes between various armed groups and terrorists for power in 2018 forced more than 4 million people to leave their homes in the African Sahel [The Sahel is engulfed... 2019]. The reasons include a combination of bad governance, inefficient economies, depreciation of local currencies, inflation, migration growth and high levels of violence [The Permanent Interstate Committee... 2019].

The current migration crisis is unique in its scale, which has become the largest since the Second World War. This crisis partially destabilized relations between states. Refugees pose a potential threat to the social, political and economic spheres. In addition, the problem of refugees cannot be overcome today because of the global nature of the problem. Abnormal climate change has led to the emergence of so-called climatic refugees. About a billion people live in areas with a high or very high level of exposure to climatic hazards, 971 million people are under the risk of extreme weather, as well as potential conflicts [Global Peace Index 2018... 2019]. Climate change is likely to damage the security of resources, livelihoods, and create increased numbers of displaced persons. Scientists predict that global warming and the exacerbation of military conflicts will contribute to the further displacement of people and may lead to an aggravation of the global socio-economic crisis. Today, one of the most pressing tasks for the international community is the search for effective constructive solutions to overcome the negative consequences of the migration problem. The purpose of this work is to identify the cause and effect of migration and emigration processes in the world with the external dimensions of socio-economic and security policies globally. 


\section{The economic effects of international migration}

There are currently more refugees on the planet than at any time in history. Instability and violence tend to play a greater part in the global population of migrants. Trillions of dollars are spent annually on militarization, security, crime and conflict, and the cost is rising. The impact of violence on the world economy in 2018 amounted to 14.1 trillion dollars. This is equivalent to $\$ 1853$ per person, or $12.4 \%$ of world GDP. In the ten most affected countries, it amounts to 30\%-68\% of their GDP. The economic impact of violence has increased by $16 \%$ since 2012 , partly due to the start of the war in Syria and the consequences of the Arab Spring [Global Peace Index 2018... 2019; 4 Things to Know... 2019].

Armed conflicts, resource wars and even global warming lead to massive migration processes. They clearly represent serious challenges for society and governance, and have a significant impact on the economies of the world. International migration is of great importance for the development of the home, transit and host countries. With the help of the relevant state policy, migration can contribute to inclusive and sustainable economic growth and development both in the countries of origin and destinations of migrants. In 2016, migrants from developing countries sent home about $\$ 413$ billion in remittances [International Migration Report 2017]. Foreign money transfers are an important source of household income. According to the International Fund for Agricultural Development (IFAD), around 800 million people worldwide are directly supported by remittances from relatives abroad, which is a real opportunity to improve the well-being of families and invest in healthcare, education, housing, infrastructure, etc. Remittances from abroad are more stable than both private debt and portfolio investment flows, and several times higher than international development assistance [How Migrants... 2019]. In addition to financial remittances, transnational communities also contribute to 'social remittances', to the flow of skills, knowledge, ideas and values that migrants transfer to their homes.

Countries of destination also gain significant benefits from migration. Migrants often fill labour gaps in those areas where locals are reluctant to fill job vacancies. Every migrant has his/her own reason to leave the house, but they all bring with themselves their life experiences, knowledge, culture and ambitions, new skills and know-how. Migrants also create new jobs as entrepreneurs and pay taxes and social security contributions. Some migrants are among the most dynamic members of the host society, which promotes the development of science and technology, the dissemination of knowledge and the enrichment of cultural diversity in host countries [International Migration Report 2017... 2019].

Europe is the most popular place of residence for migrants. It accepts one third of all the world's migrants. Half of them are Europeans themselves who want to live in richer countries than their own [These 9 charts... 2019]. 
From the economic point of view, the influx of migrants into developed countries opens new opportunities for the development of regions. Taking into account the demographic trends of ageing in almost every one of these countries, foreign workers can be an important complement to the local labour force. This is especially true about migrants with high qualifications in medicine, education and science. Additionally international migration has a positive impact on GDP and contributes to the rebirth of 'ghost towns' and economic growth in general. Historically, refugees make the world a better place to live [Migration benefits all of us... 2019].

There is unconditional evidence that migration contributes to economic growth [Dustmann, Frattini 2013; Kovalchuk et al. 2017]. A recent study by UK scientists has shown that in the first decade of the 21st century, migrants from the European Economic Area (EEA) made a net contribution of 25 billion GBP to public finances. They paid $34 \%$ more taxes than they received as privileges. According to the World Bank, an increase in immigration at a level equivalent to $3 \%$ of the labour force in developed countries will lead to global economic benefits of 356 billion dollars. In the US, immigrants were founders of such companies as Google Intel, PayPal, eBay and Yahoo! Experienced immigrants make up more than half of the startups in Silicon Valley and more than half of the patents, although they make up less than $15 \%$ of the population [It's Time to Restate... 2019].

However, in order to achieve economic growth, migration needs to be managed well at state level. Reliable information for decision-making can be based only on the results of the development and use of adequate econometric models for identifying the links between migration processes and key indicators of national economies.

\section{Related research}

Uncertainty about data and factors that determine the dynamics of migration flows requires systematic evaluation. To study the peculiarities of global migration processes, it is necessary to use a wide range of information sources and tools for the econometric models development. The study of this issue is constantly addressed by many scientists from all the world. However, there is no consensus among scientists on assessing the benefits and losses of large-scale human displacements. In addition, in recent years, the new global problems have a significant impact on this process, among them are climate change, resource wars, the growth of terrorist activity and the significant exacerbation of international conflicts. Most academic publications are devoted to regional studies for individual countries and regions, the relation (or effect) between international migration and one of the economic indicators, which is usually Foreign Direct Investment.

A. Garas, A. Lapatinas, K. Poulios explored, based on a panel data analysis, the relationship between human migration and OECD's foreign direct investment [Garas et al. 2016]. J. Alcaraz and E. Salamanca identified the relationship between the international movement of enterprises and their location, and the direction of international migration (immigration/emigration) [Alcaraz, Salamanca 2018]. 
K.F. Davis, P. D'Odorico, F. Laio, and L. Ridolfi found that distinct groups of countries preferentially interact to form migration communities based largely on historical, cultural and economic factors [Davis et al. 2013]. R. Black, W.N. Adger, N. Arnell, S. Dercon, A. Geddes, and D.S.G. Thomas studied the influence of the environment and environmental changes [Black et al. 2012]. G. Fagiolo and M. Mastrorillo explored the relationships between international human migration and merchandise trade using a complex-network approach [Fagiolo, Mastrorillo 2014]. A. Tomohara investigated the dynamic interactions between immigration and foreign direct investment (FDI) using bilateral data between Japan and each of the 29 countries / economies of origin for both FDI and immigrants into Japan during the period from 1996 to 2011. He established that immigration flows discourage FDI inflows (FDI-migration substitution), although larger immigration 'stocks' trigger FDI inflows (ethnic net externalities) [Tomohara 2017].

As the population movements tend to increase, further studies of the dynamics of the interactions between the macroeconomic processes of the global economy and international migration are relevant.

\section{Data and empirical findings}

\section{Data and definitions variables}

In order to assess the international migration situation worldwide, the authors have used the following UN indicators: International Migrant Stock and Estimated Fugue stock. By definition, an international migrant is a person living in a different country than the country of birth. To assess the international stock of migrants, birthplace data is a major source of information. Estimates of the size (or 'stock') of international migrants from the territory of origin, presented in the International Migration Report 2017, are based on national statistics, in most cases obtained from population censuses. In addition, population registers and national representative surveys provide information about the number and composition of international migrants.

A series of empirical studies conducted by the authors on the formation of an optimal set of indicators for measuring the socio-economic development of regions in the context of international migration processes [Kovalchuk 2017; Kovalchuk et al. 2017] gives reasons to use the following common indicators in our study: Income Rate of United Nations [Trends in International Migrant Stock: The 2017 revision], GDP per capita, PPP (current international \$) [GDP per capita... 2018], Inflation Rate (average consumer prices, annual percent change) and Unemployment rate of the International Monetary Fund [Inflation rate... 2019] the Gini Index (World Bank estimate), that measures the level of inequality in the distribution of household income in the country [GINI index 2018] and Foreign Direct Investment, net inflows (BoP, current US \$) [Foreign Direct Investment, Net Inflows].

In conducting empirical studies the following security indicators of the world which most closely related to international migration [Kovalchuk 2017] are used: 
Global Terrorism Index produced by the Institute for Economics \& Peace [Global Terrorism Index 2017] (GTD is considered the most comprehensive global dataset on terrorist activity), the number of ongoing crises and disasters (calculated on the basis of the official overviews, news, analyses of crises and disasters by country, that updates by country every 72 hours) [An ongoing crisis... 2019] and the Global Peace Index (GPI), which looks at the "harmony achieved by the lack of violence or fear of violence". This is called a negative world and is measured by using three areas for GPI: current domestic and international conflicts, societal safety and security, and militarization [Global Peace Index 2018... 2019].

Since the latest available data on International Migrant Stock and Refugee Stock (measurement of persons) for 2017, the authors research has used all the data for that year. Factor Analysis and Cluster Analysis have been used to identify the possible relationship between migration processes, the level of socio-economic development and security aspects of the world.

\section{Results of $k$-means clustering}

A cluster analysis was carried out using the $k$-means clustering method to divide countries into groups according to the indicators selected for analysis.

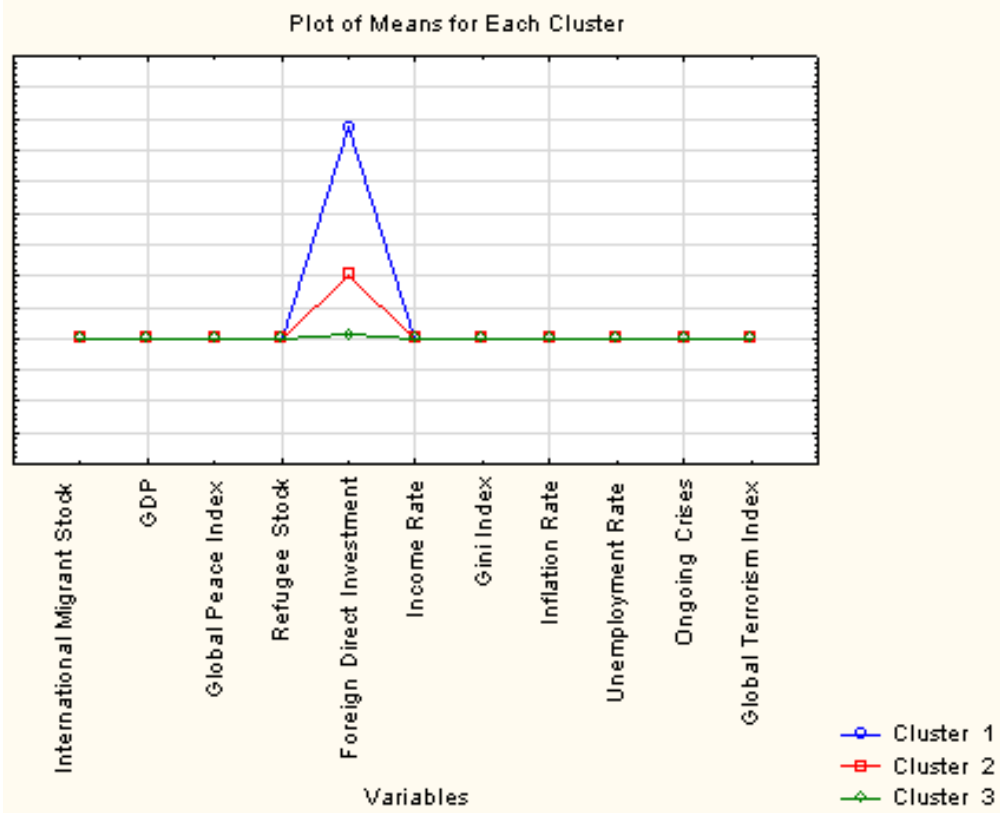

Fig. 1. Plot of means for each cluster

Source: own study. 
In general, 201 countries were selected for analysis. However, in the absence of statistical indicators selected for analysis, only 85 observations were valid. As a result of empirical studies, three clusters have been identified. The variable FDI has the largest impact on the division of powers into groups (Figure 1).

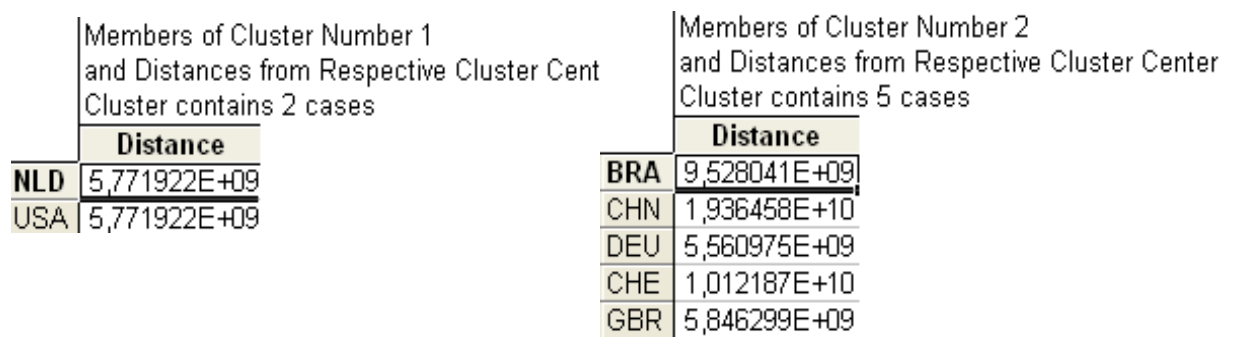

\begin{tabular}{l|c|}
\hline & \multicolumn{2}{|c}{$\begin{array}{l}\text { Members of Clus } \\
\text { and Distances fr } \\
\text { Cluster contains }\end{array}$} \\
\cline { 2 - 3 } & Distance \\
\hline ALB & $1,503457 \mathrm{E}+09$ \\
\hline DZA & $1,449537 \mathrm{E}+09$ \\
\hline ARG & $1,660823 \mathrm{E}+09$ \\
\hline ARM & $1,736336 \mathrm{E}+09$ \\
\hline AUS & $1,159950 \mathrm{E}+10$ \\
\hline AUT & $2,894351 \mathrm{E}+09$ \\
\hline AZE & $9,470613 \mathrm{E}+08$ \\
\hline BLR & $1,426822 \mathrm{E}+09$ \\
\hline BEL & $1,371600 \mathrm{E}+10$ \\
\hline BTN & $1,816632 \mathrm{E}+09$ \\
\hline BOL & $1,596822 \mathrm{E}+09$ \\
\hline BIH & $1,672122 \mathrm{E}+09$ \\
\hline BGR & $9,574505 \mathrm{E}+08$ \\
\hline CAN & $6,575564 \mathrm{E}+09$ \\
\hline CHL & $4,714207 \mathrm{E}+07$ \\
\hline COL & $2,360119 \mathrm{E}+09$ \\
\hline CRI & $9,505228 \mathrm{E}+08$ \\
\hline HRV & $1,196419 \mathrm{E}+09$ \\
\hline CYP & $1,510654 \mathrm{E}+09$ \\
\hline CZE & $1,575761 \mathrm{E}+09$ \\
\hline
\end{tabular}

\begin{tabular}{l|l} 
DNK & $1,100866 \mathrm{E}+09$ \\
\hline DOM & $7,268335 \mathrm{E}+08$ \\
\hline ECU & $1,625175 \mathrm{E}+09$ \\
\hline EGY & $4,221661 \mathrm{E}+08$ \\
\hline SLV & $1,659739 \mathrm{E}+09$ \\
\hline FIN & $2,388291 \mathrm{E}+09$ \\
\hline FRA & $1,246058 \mathrm{E}+10$ \\
\hline GEO & $1,259896 \mathrm{E}+09$ \\
\hline GRC & $7,348641 \mathrm{E}+08$ \\
\hline HND & $1,430356 \mathrm{E}+09$ \\
\hline HUN & $5,714956 \mathrm{E}+09$ \\
\hline ISL & $3,922188 \mathrm{E}+09$ \\
\hline IDN & $4,372450 \mathrm{E}+09$ \\
\hline IRN & $2,983561 \mathrm{E}+08$ \\
\hline IRL & $2,847629 \mathrm{E}+09$ \\
\hline ISR & $3,666488 \mathrm{E}+09$ \\
\hline ITA & $9,464909 \mathrm{E}+08$ \\
\hline JAM & $1,543647 \mathrm{E}+09$ \\
\hline JPN & $4,345191 \mathrm{E}+09$ \\
\hline JOR & $1,199658 \mathrm{E}+09$
\end{tabular}

\begin{tabular}{l|l} 
KAZ & $3,907299 \mathrm{E}+08$ \\
\hline KOR & $3,589302 \mathrm{E}+09$ \\
\hline KGZ & $1,843967 \mathrm{E}+09$ \\
\hline LVA & $1,468621 \mathrm{E}+09$ \\
\hline LTU & $1,452653 \mathrm{E}+09$ \\
\hline MKD & $1,696844 \mathrm{E}+09$ \\
\hline MYS & $1,056242 \mathrm{E}+09$ \\
\hline MUS & $1,723404 \mathrm{E}+09$ \\
\hline MEI & $7,545105 \mathrm{E}+09$ \\
\hline MDA & $1,763146 \mathrm{E}+09$ \\
\hline MNG & $1,361078 \mathrm{E}+09$ \\
\hline MAR & $1,003558 \mathrm{E}+09$ \\
\hline MMR & $6,048647 \mathrm{E}+08$ \\
\hline NIC & $1,578905 \mathrm{E}+09$ \\
\hline NGA & $7,571855 \mathrm{E}+08$ \\
\hline NOR & $9,028525 \mathrm{E}+05$ \\
\hline PAK & $9,215799 \mathrm{E}+08$ \\
\hline PRY & $1,658782 \mathrm{E}+09$ \\
\hline PER & $2,294394 \mathrm{E}+08$ \\
\hline PHL & $1,280793 \mathrm{E}+09$
\end{tabular}

\begin{tabular}{l|l} 
POL & $1,406390 \mathrm{E}+09$ \\
\hline PRT & $1,210395 \mathrm{E}+09$ \\
\hline ROU & $1,677356 \mathrm{E}+07$ \\
\hline SRB & $9,394677 \mathrm{E}+08$ \\
\hline SVK & $2,620487 \mathrm{E}+07$ \\
\hline SVN & $1,485442 \mathrm{E}+09$ \\
\hline ZAF & $1,190569 \mathrm{E}+09$ \\
\hline ESP & $5,887477 \mathrm{E}+07$ \\
\hline LKA & $1,397095 \mathrm{E}+09$ \\
\hline SDN & $1,490441 \mathrm{E}+09$ \\
\hline SWE & $5,478897 \mathrm{E}+09$ \\
\hline THA & $6,141713 \mathrm{E}+08$ \\
\hline TTO & $1,949390 \mathrm{E}+09$ \\
\hline TUN & $1,567508 \mathrm{E}+09$ \\
\hline TUR & $1,669609 \mathrm{E}+09$ \\
\hline UKR & $9,592692 \mathrm{E}+08$ \\
\hline URY & $1,030237 \mathrm{E}+019$ \\
\hline VNM & $2,439669 \mathrm{E}+09$
\end{tabular}

Fig. 2. Members of each clusters and distances from Respective Cluster Center

Source: own study.

The first cluster is formed by two countries - the USA and the Netherlands (Figure 2). They are characterized by being several times higher than in other groups, the average values of the variables International Migrant Stock and FDI, high GDP and Refugee Stock. These countries also have a low Inflation Rate, Unemployment 
Rate and Gini Index. These two highly developed countries are most refugee-friendly and have the highest level of displaced migrants in search of a better life (Figure 3). Although these countries are among the most expensive places to live, immigrants feel financially safe and stay there for a long time.

\begin{tabular}{|c|c|c|c|}
\hline \multirow[b]{2}{*}{ Variable } & \multicolumn{3}{|l|}{ Cluster Means } \\
\hline & $\begin{array}{c}\text { Cluster } \\
\text { No. } 1 \\
\end{array}$ & $\begin{array}{l}\text { Cluster } \\
\text { No. } 2\end{array}$ & $\begin{array}{l}\text { Cluster } \\
\text { No. } 3\end{array}$ \\
\hline International Mig & $2,591674 \mathrm{E}+07$ & $5,049656 \mathrm{E}+06$ & $1,268342 \mathrm{E}+06$ \\
\hline Refugee Stock & $4,649555 \mathrm{E}+05$ & $3,722462 E+05$ & $1,523679 \mathrm{E}+05$ \\
\hline Global Peace Index & $1,937000 E+00$ & $1,843400 \mathrm{E}+00$ & 1,957 \\
\hline GDP & $5,717497 \mathrm{E}+04$ & $3,924292 \mathrm{E}+04$ & 2,3889 \\
\hline Foreign Direct & $3,356847 \mathrm{E}+11$ & $1,018587 E+11$ & $6,008534 \mathrm{E}+09$ \\
\hline Income Rate & $1,010000 \mathrm{E}+02$ & $1,020000 E+02$ & $1,028462 \mathrm{E}+02$ \\
\hline Gini Index & 3,485 & 3,7820 & 3,5820 \\
\hline Inflation Rate & $1,900000 E+00$ & $2,260000 E+00$ & $5,083333 \mathrm{E}+00$ \\
\hline Unemploymen & $4,650000 \mathrm{E}+00$ & $5,620000 \mathrm{E}+00$ & $8,510257 \mathrm{E}+00$ \\
\hline Ongoing Crises and Dis & $4,306000 E+03$ & $3,063000 E+013$ & $4,971167 E+03$ \\
\hline Global Terrorism Index & $3,920500 E+00$ & $3,480600 \mathrm{E}+00$ & $2,527974 \mathrm{E}+00$ \\
\hline
\end{tabular}

Fig. 3. Cluster Means

Source: own study.

The second cluster includes Brazil, China, Germany, Switzerland, and the United Kingdom (Figure 2). For countries in this cluster, the average mean of most variables is the average mean of the three selected groups. Countries in the second cluster are the safest places to live - the mean of the Global Peace Index and the Ongoing Crises and Disasters is minimal among all the clusters. However, the level of Foreign Direct Investment is the smallest in this group (Figure 3).

All the other 78 countries of the world are in the third cluster. They are characterized by the maximum mean of the Global Peace Index, which indicates a low level of social protection and security, militarization and conflicts in these countries. The states in the third cluster have the highest level of Inflation Rate, Unemployment Rate and Ongoing Crises and Disasters, and the minimum ones for GDP and Global terrorism Index. This largest group of countries is the least attractive to refugees. The average number of migrants, as well as Foreign Direct Investment, for third-cluster countries is the smallest among other groups (Figure 3).

\section{Results of principal components analysis}

One of the methods of factor analysis (principal components analysis) is used to identify the alleged non-obvious patterns that are caused by the influence of external (internal) economic and security factors on the dynamics of indicators of migration processes, the identification and study of the statistical connection of the distinguished features with the essential factors. 
The Scree plot (Plot of Eigenvalues) criterion provided by Statistica software package was used to select the optimal number of factors. For each of the selected factors, the load of each of the measured characteristics is determined. The resulting factor loads can be interpreted as correlations between the analyzed indicators and factors. The complexity of the links is estimated by the magnitude of the absolute value of the factor load (Figure 4).

\begin{tabular}{l|r|rl} 
Variable & Factor & Factor & \\
\cline { 1 - 3 } International Migrant Stock & $-0,115976$ & 0,846795 & \\
\cline { 1 - 3 } Refugee Stock & 0,275424 & 0,524637 & \\
\cline { 1 - 3 } Global Peace Index & 0,870265 & 0,197556 & \\
\hline GDP & $-0,765808$ & 0,440229 & \\
\hline Foreign Direct Investment & $-0,196969$ & 0,768824 & \\
\hline Income Rate & 0,752743 & $-0,303556$ & \\
\hline Gini Index & 0,431735 & 0,021415 & \\
\hline Inflation Rate & 0,606352 & 0,101467 & Fig. 4. Factor Loadings (Varimax \\
\hline Unemployment Rate & 0,415069 & $-0,066336$ & normalized) \\
\cline { 1 - 3 } Ongoing Crises and Disasters & 0,793816 & 0,197548 & \\
Global Terrorism Index & 0,547455 & 0,561718 & Source: own study.
\end{tabular}

As a result, two factors were determined. The first of these factors is closely related to the Global Peace Index, Ongoing Crises and Disasters and GDP (reverse correlation).

The second one is mostly influenced by the International Migrant Stock and FDI (marked loadings are more than 0,7 ), which is confirmed by the factor load schedule (Figure 5).

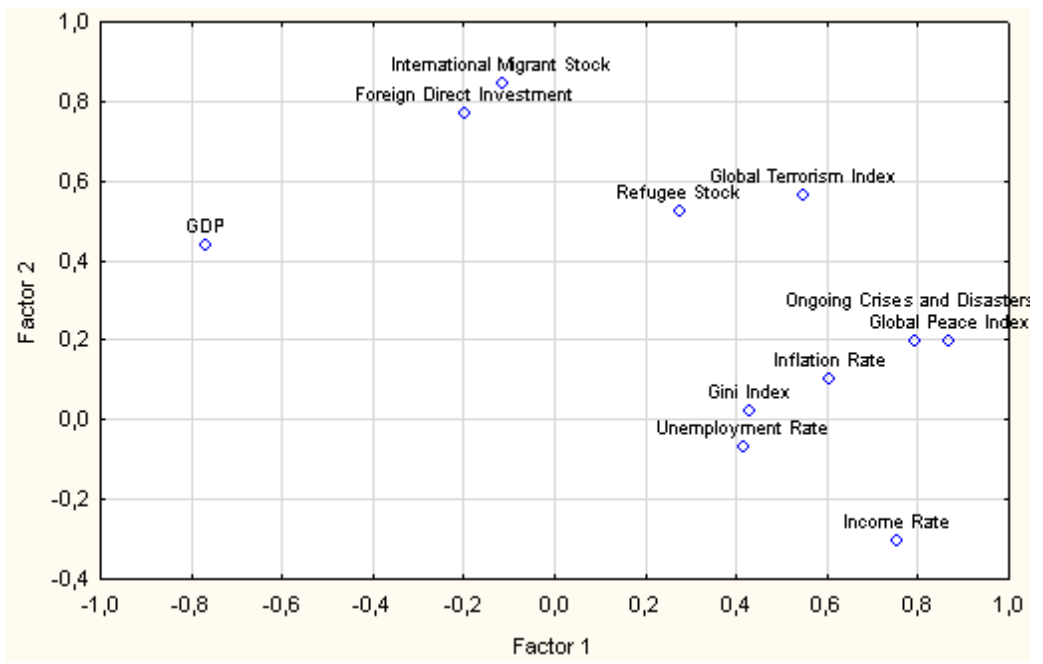

Fig. 5. Factor Loadings (Varimax normalized)

Source: own study. 
To determine the significance of the selected factors, an analysis of the factors eigenvalues was performed (Figure 6). Eigenvalues are dispersions that are explained by the relevant factors.

Fig. 6. Eigenvalues selected factors

Source: own study.

\begin{tabular}{l|r|r|r|r} 
Value & Eigenvalue & $\begin{array}{c}\% \text { Total } \\
\text { variance }\end{array}$ & $\begin{array}{c}\text { Cumulative } \\
\text { Eigenvalue }\end{array}$ & $\begin{array}{c}\text { Cumulative } \\
\%\end{array}$ \\
\hline $\mathbf{1}$ & 3,640532 & 36,40532 & 3,640532 & 36,40532 \\
\hline $\mathbf{2}$ & 2,092034 & 20,92034 & 5,732567 & 57,32567 \\
\hline
\end{tabular}

The first isolated factor explains $36.4 \%$ of the dispersion, the second $-21 \%$. Together, they describe $57.4 \%$ of the dispersion, that is more than half of the data range. This means that the factorization carried out is not complete, there are also other factors that are less significant, but they are also quite important. In particular, the rights and freedoms, accessibility and quality of medicine and education, social guarantees, religion, migration policy, tolerance for displaced persons, etc. are not included in the proposed model. All these factors may have a different effect on global migration processes.

As a result of the analysis, the following factor model was obtained:

$$
\begin{gathered}
F_{1}=0.90 \cdot G P I+0.75 \cdot I P+0.80 \cdot C D+0.80 \cdot G D P, \\
F_{2}=0.85 \cdot I M+0.70 \cdot F D I .
\end{gathered}
$$

Note: in the model (1)-(2) the following notation is used: GPI - Global Peace Index, IR - Inflation Rate, CD - Ongoing crises and disasters, IM - International migrant stock, FDI - Foreign Direct Investment.

Factor 1 can be interpreted as economic-security, factor 2 - as the so-called "FDI-migration effect". They are linear combinations of the analyzed indicators and reflect the overwhelming part of the overall variability of the studied features, therefore retaining the bulk of the information contained in the initial data.

In order to distinguish the main factors of the immigration and emigration processes, the following factor models were constructed (Figures 7 and 8):

$$
\begin{gathered}
F_{1}^{e m}=0.74 \cdot G P I+0.84 \cdot I R+0.90 \cdot G D P, \\
F_{2}^{e m}=0.70 \cdot G T I .
\end{gathered}
$$

Note: in models (3) to (4) the designation of models (1) to (2), and also GTI Global Terrorism Index are used.

$$
\begin{gathered}
F_{1}^{i m}=0.90 \cdot G P I+0.70 \cdot I R+0.82 \cdot C D, \\
F_{2}^{i m}=0.87 \cdot I M+0.80 \cdot F D I .
\end{gathered}
$$




\begin{tabular}{l|r|r}
\cline { 2 - 3 } \multicolumn{1}{l|}{ Variable } & \multicolumn{1}{c|}{$\begin{array}{c}\text { Factor } \\
\text { Refugee Stock }\end{array}$} & $\begin{array}{c}\text { Factor } \\
\text { Ren }\end{array}$ \\
\hline Global Peace Index & 0,018990 & 0,664575 \\
\hline GDP & 0,737504 & 0,498429 \\
\hline Foreign Direct Investment & $-0,903268$ & 0,172938 \\
\hline Income Rate & $-0,420340$ & 0,528588 \\
\hline Gini Index & 0,844117 & $-0,060707$ \\
\hline Inflation Rate & 0,443129 & 0,077774 \\
\hline Unemployment Rate & 0,491624 & 0,387331 \\
\hline Ongoing Crises and Disasters & 0,405717 & 0,104325 \\
\hline Global Terrorism Index & 0,644046 & 0,514898 \\
\hline & 0,262930 & 0,788282 \\
\hline
\end{tabular}

\begin{tabular}{l|c|c} 
Variable & Factor & Factor \\
\cline { 1 - 1 } Global Peace Index & $\mathbf{1}$ & 2 \\
\hline GDP & 0,891289 & 0,071267 \\
\hline Foreign Direct Investment & $-0,698059$ & 0,534286 \\
\hline Income Rate & 0,059788 & 0,839904 \\
\hline Gini Index & 0,412129 & $-0,381466$ \\
\hline Inflation Rate & 0,611229 & $-0,010622$ \\
\hline Unemployment Rate & 0,000833 \\
\hline Ongoing Crises and Disasters & 0,824688 & $-0,170376$ \\
\hline Global Terrorism Index & 0,620223 & 0,101051 \\
\hline International Migrant Stock & 0,016799 & 0,8765075 \\
\hline
\end{tabular}

Fig. 7. Factor Loadings

for emigrations

Source: own study.

The results of the analysis show that the emigration processes are closely related to the host country's economic and security aspects, in particular the Inflation Rate, GDP, Global Peace Index, and Global Terrorism Index. For migration flows, in addition to the Inflation Rate and the Global Peace Index, Outgoing Crises and Disasters, and FDI, which are closely interrelated with International Migrant Stock, are decisive. Thus it can be said that the settlers, for the most part, are seeking asylum in peaceful, economically developed countries, which increases the risk of spreading terrorism in their home territory. Migrants, in the main, seeking a better life, leave countries in which security is not guaranteed. These same migrants substantially stimulate the economies of their home countries through foreign direct investment.

\section{Conclusions}

Migration has become one of the greatest problems of the modern dynamically militarized world. The governments of countries cannot cope with the situation and need international assistance. Host countries are concerned about the socio-economic, political and security implications of international migration, and home countries are concerned about the brain drain and the loss of the younger population. The world cannot hope for safe, orderly and regulated migration without the adoption of effective management decisions.

This study applied economic and mathematical methods to identify the critical factors that are the causes and consequences of modern migration processes. 
A cluster model of distribution of countries around the world based on the basic indicators related to people's movements has been constructed. The obtained results were verified using Principal Components Analysis. The factor models have been constructed separately for emigration and immigration processes and for international migration in general. The main factors that cause people to flee from their native country in search of a better life (migration), or to choose a foreign country for permanent residence (refugee) are revealed. The results of the constructed models confirmed the causal link between international migration flows and the growth of FDI in their home countries and the reduction of security in the host countries. As a result of empirical studies, no link was found between the international migration (immigration/emigration) and the Unemployment Rate and the Gini Index, which measures the level of inequality in the distribution of household income in the country.

Accurate, consistent, and timely data about international migration are essential for assessing current and future trends, as well as for prioritizing the socio-economic and security policies of the world's nations. The obtained results can provide competitive advantages in shaping socio-economic, political and security decisions.

\section{Bibliography}

4 Things to Know about the State of Conflict Today, 2019, World Economic Forum, https://www.weforum.org.

Alcaraz J., Salamanca E., 2018, Migration and outward FDI: A double direction approach, Review of International Business and Strategy, vol. 28, Issue: 2, pp. 240-257.

An Ongoing Crisis and Disasters, 2019, Relifweb, https://reliefweb.int/countries.

Basel Anti-Money Laundering Index, 2018, International Centre For Asset Recovery, https://index.baselgovernance.org.

Black R., Adger W., Arnell N., Dercon S., Geddes S., Thomas D., 2012, The effect of environmental change on human migration, Global Environmental Change, vol. 21, pp. 3-11.

Davis K., D’Odorico P., Laio F., Ridolfi L., 2013, Global Spatio-Temporal Patterns in Human Migration: A Complex Network Perspective, PloS One, vol. 8(1), https://www.ncbi.nlm.nih.gov/.

Dustmann C., Frattini T., 2013, The Fiscal Effects of Immigration to the UK, Centre for Research and Analysis of Migration, Drayton House, London, http://www.cream-migration.org.

Fagiolo G., Mastrorillo M., 2014, Does human migration affect international trade? A complexnetwork perspective; PLoS One, vol. 9(5), Published online 2014 May 14, https://www. ncbi.nlm.nih.gov/pmc/articles/PMC4020834.

Foreign direct investment, net inflows (BoP, current US\$), 2018, The World Bank, https://data. worldbank.org/indicator/BX.KLT.DINV.CD.WD.

Garas A., Lapatinas A., Konstantinos Poulios K., 2016, The relation between migration and FDI in the OECD from a complex network perspective, Advances in Complex Systems, vol. 19, issue 06n07, pp. 1-20.

GDP per capita, PPP (current international \$), 2018, The World Bank, https://data.worldbank. org/indicator/NY.GDP.PCAP.PP.CD.

GINI Index, 2018, The World Bank, https://data.worldbank.org/indicator/si.pov.gini

Global Peace Index 2018: Measuring Peace in a Complex World, 2019, Institute for Economics \& Peace, http://visionofhumanity.org/reports.

Global Terrorism Index 2017, 2018, Institute For Economics \& Peace, http://visionofhumanity.org/ app/uploads/2017/11/Global-Terrorism-Index-2017.pdf. 
Global Trends: Forced Displacement in 2018, 2019, United Nations, The UN Refugee Agency, https://www.unhcr.org.

How Migrants Who Send Money Home Have Become a Global Economic Force, 2019, World Economic Forum, https://www.weforum.org.

Inflation Rate, Average Consumer Prices, 2019, International Monetary Fund, https://www.imf.org.

International Migration Report 2017: Highlights, 2019, United Nations, Department of Economic and Social Affairs, https://www.un.org.

It's Time to Restate the Business Case for Migration, 2019, World Economic Forum, https://www. weforum.org.

Kovalchuk O., 2017, Mathematical Modeling of Sustainable Development. Monograph, TNEU, Ternopil.

Kovalchuk O., Strelbitska N., Slobodian A., 2017, Foreign direct investments and their impact on economic development, Young Scientist, vol. (45), pp. 596-602.

Migration Benefits All of Us. These Stories Show How, 2019, World Economic Forum, https://www.weforum.org.

The Number of Displaced People in the World Just Hit a Record High, 2019, World Economic Forum, https://www.weforum.org.

The Permanent Interstate Committee for Drought Control in the Sahel, 2019, United Nations Office for Disaster Risk Reduction, https://www.preventionweb.net.

The Sahel is engulfed by Violence. Climate Change, Food Insecurity and Extremists are Largely to Blame, 2019, World Economic Forum, https://www.weforum.org.

These 9 Charts Will Tell You Everything you Need to Know about Global Migration, 2019, World Economic Forum, https://www.weforum.org.

Tomohara A., 2017, Does immigration crowd out foreign direct investment inflows? Tradeoff between contemporaneous FDI-immigration substitution and ethnic network externalities, Economic Modelling, vol. 64, pp. 40-47.

Trends in International Migrant Stock: The 2017 Revision, 2017, United Nations, Department of Economic and Social Affairs (United Nations database), https://www.dhs.gov/immigrationstatistics/special-reports/legal-immigration.

\section{MODELOWANIE CZYNNIKÓW ZWIĄZANYCH ZE SKUTKAMI MIĘDZYNARODOWEJ MIGRACJI DLA BEZPIECZEŃSTWA I GOSPODARKI}

Streszczenie: Niniejszy artykuł bada związki przyczynowo-skutkowe pomiędzy współczesnymi globalnymi procesami migracyjnymi a podstawowymi wskaźnikami społeczno-ekonomicznymi oraz wskaźnikami bezpieczeństwa dla krajów świata. Na podstawie nowych oficjalnych zestawów danych opracowano klastrowy model rozmieszczenia krajów świata według głównych wskaźników charakteryzujących przepływy migracyjne (emigracyjne/imigracyjne), mierników bezpieczeństwa oraz wskaźników makroekonomicznych związanych z międzynarodowymi przepływami ludności. Stwierdzono, że ludzie przenoszą się do bezpieczniejszych krajów, które mogą zapewnić im lepsze możliwości i gwarancje społeczne. Skonstruowano modele czynnikowe dla procesów emigracyjnych, imigracyjnych oraz migracji międzynarodowej w ogóle. Określono podstawowe przesłanki zmuszające ludzi do opuszczenia kraju pochodzenia oraz ekonomiczne czynniki i czynniki bezpieczeństwa bezprecedensowego poziomu migracji międzynarodowej. Badania empiryczne, które zostały przeprowadzone w tym artykule, potwierdzają związek przyczynowo-skutkowy pomiędzy wielkością międzynarodowych przepływów migracyjnych a wzrostem bezpośrednich inwestycji zagranicznych w krajach macierzystych oraz spadkiem bezpieczeństwa w krajach przyjmujących. Stwierdzono brak statystycznego związku między przepływami imigracyjnymi i emigracyjnymi.

Słowa kluczowe: migracja międzynarodowa, wzrost gospodarczy, bezpieczeństwo, zmiana klimatu, modelowanie. 